Making little neoliberals: the production of ideal child/learner subjectivities in primary school through choice, self-improvement and 'growth mindsets'

Alice Bradbury

UCL Institute of Education, University College London, London, UK

UCL Institute of Education,

University College London,

20 Bedford Way

London WC1H 0AL

a.bradbury@ucl.ac.uk

@alicejbradbury 


\title{
Making little neoliberals: the production of ideal child/learner subjectivities in primary school through choice, self-improvement and 'growth mindsets'
}

\begin{abstract}
This paper aims to look at the intersection of policy and lived experience at the level of the individual child, by dissecting how primary education policy in England demands and expects a particular learner subjectivity. The focus is on children in the first years of primary school, and how statutory assessments provide a model of the 'ideal learner' who is self-regulating and able to make choices which are self-improving. The paper uses data collected through qualitative research projects conducted in the late 2000s and in 2015-7, involving interviews with teachers and school leaders and observation in classrooms, to consider how this model of the neoliberal learner has evolved. Drawing on theoretical insights on the 'neoliberal subject' (Walkerdine 2003) and post-structural insights into subjectivity and acceptable/impossible learner identities (Youdell 2006), it is argued that despite some shifts towards valuing high attainment in 'measurable' subjects within data-obsessed school system (Bradbury and Roberts-Holmes 2017c), there remains a broad conception of the 'good learner' in early years which includes attitudes to learning and self-regulation. This wider view is encouraged by the discourse of 'growth mindset' and the recent focus on Character Education, and has social justice implications.
\end{abstract}

\section{Introduction}

This paper aims to explore how policy shapes the lived experiences of children in the early years of primary education in England, through a discussion of how assessment content and current individualising discourses require children to become self-regulating and self- 
improving learners, or little neoliberals. Although neoliberal ideology has influenced early childhood education internationally, England is an international outlier in terms of regulation in early childhood, in that children are required to start compulsory schooling earlier than elsewhere and are subject to a statutory curriculum and assessment regime from the age of four (DfE 2014a). The 'early years' part of primary education, made up of voluntary Nursery classes for three and four-year-olds and compulsory Reception classes of four- and five-yearolds, represents a hinterland between the more formal practices of primary education and the play-based ethics of pre-school settings such as nurseries (Moss 2013). As such, the early years are the location of constant debate and contestation between policy agendas which emphasise school readiness and the benefits of early intervention, and professional discourses which focus on care, the value of play and recognition of the 'whole child' (Carr 2013; Gillies et al. 2017; Moss 2013). This paper demonstrates how the early years in England provide an example of the dominance of neoliberal ideas, and the potential exclusionary impact.

The policy context in England is distinctive in that is productive of a particular, restrictive learner subjectivity. Early years classrooms in England are subject to statutory assessment: at present the Early Years Foundation Stage Profile (EYFS Profile) must be completed in June of the Reception year for each child. This involves a teacher judgement on whether each child has reached 'expected' levels in 17 Early Learning Goals, or has 'exceeded' these, or is deemed 'emerging'. Additionally, there have been policy forays into a statutory assessment on entry, known as Baseline Assessment (which I discuss in more detail below). The current and long-established EYFS Profile, as a detailed assessment on each child based on observation through the year, provides a frame for understanding what constitutes a 'good' four- or five-year-old school student, and who falls outside of this designation. 
The paper uses data collected through qualitative research projects conducted in the late 2000s and in 2017, involving interviews with teachers and school leaders and observation in classrooms. Drawing together data over this period allows from some observation of how changes in assessment regimes have altered models of good learner subjectivities, though my overall argument is that policy discourses are marked by continuity, notably in the importance placed upon making good choices. The focus is on the distinctively neoliberal elements of the idealized student subjectivity in early years, drawing on theoretical insights on the 'neoliberal subject' (Walkerdine 2003), and post-structural insights into subjectivity and acceptable/impossible learner identities (Youdell 2006). The aim is to answer two main questions: first, how does neoliberal policy shape learner subjectivities in early years? Second, how have these changed with policy reforms? In doing so, I consider how neoliberal policy demands neoliberal subjects - in this case, little neoliberals - and then in the discussion section I reflect on what this means for the reproduction of inequalities in education.

\section{The neoliberal regime in early years}

Early childhood education and care for children aged 0-5 years has been a policy focus internationally since the late 1990s. The increased investment in early childhood seen in the 2000s in countries such as the US, Australia and the UK has been accompanied by marketbased reforms driven by neoliberal ideology (Dahlberg and Moss, 2005), such as voucher schemes and competition between providers. In this context, investment in early years is justified using human capital theory, which suggests that spending money on children in their first few years will yield gains as they require fewer services as adults. This is 'the story of quality and high returns' as Moss terms it (2014), where the result of investment and high quality provision is increased human capital and decreased dysfunction. The desire for accountability has led to a need for measurement, so that early childhood becomes dominated 
by a calculative rationality. Dahlberg and Moss argue policy is 'stirred by the prospect of preschools being sites for producing predefined outcomes, mainly through the application of technical practices to the efficient governing of children' (2005 p4). The drive to raise standards overall also has implications for practice, with increasing pressure on pre-school settings to prepare children for compulsory schooling (Moss 2013; Rose and Rogers 2012) and a resulting critique of the social and emotional impact of 'schoolification' (OECD 2006; see also Gunnarsdottir 2014).

In England, early childhood has been subject to increasing regulation, and similar concerns have been raised about greater formalisation. Education for children under five in England is governed by the Early Years Foundation Stage Framework (DfE 2014a), a curriculum which differs from the National Curriculum which is statutory in state schools from Year 1 (age 5-6). The awkwardly-named EYFS covers all broad range of areas including personal and social development, creative development and physical development, as well as literacy and mathematical skills. Since 2003 children in Reception (age 4-5) have been assessed through a statutory assessment known as the EYFS Profile. Teachers assess children on whether they meet 17 specific early learning goals across the broad curriculum, and report this in June each year. The EYFS Profile has been reformed and renamed since 2003 (it was previously the Foundation Stage Profile), with the main change coming in 2012 when the new Conservative-Liberal Democrat Coalition government reduced the number of points teachers had to make decisions upon from 117 to 17 . At the time of writing, teachers are required to designate each child as 'exceeding', 'expected' or 'emerging' in relation to these 17 goals covering all areas of the curriculum (DfE 2017b); these translate into one, two or three points per goal, providing an overall score ranging from 17 to 54 for each child.

In addition to this assessment, there was an attempt to introduce an assessment on entry, known as Baseline Assessment, in 2015. This assessment, conducted within the first 
six weeks of school, was intended to be used as a starting point for measuring a child's progress through primary school over seven years, so that the school's 'effectiveness' overall could be assessed (DfE 2016). However, following a widespread campaign against the new tests (BWB 2015), research that founds teachers saw the assessment as unnecessary and unhelpful (Bradbury and Roberts-Holmes 2016b), and doubts over the comparability of different providers (STA 2016), the policy was abandoned in 2016. Nonetheless, in 2017 plans were announced to reintroduce a revised form of Baseline in 2020 (DfE 2017a).

Thus the school-based early years in England are a site of neoliberal policy experimentation, fully integrated into the heavily marketised and accountability-driven policy regime (Moss 2016). While there are distinctive features of early years such as the different regulations in terms of staff qualifications, different curriculum and a specific assessment which goes beyond the core subjects of literacy and mathematics (both assessed at age seven and 11), early years remain under the jurisdiction of the primary school headteacher and there is a significant impact on the early years from the pressures faced by the rest of the school. Notably, the inclusion of EYFS Profile results in schools' data profiles for the Office for Standards in Education (the school inspection service, known as Ofsted) has led to an increased focus on early years results as part of the school's 'Ofsted story', the narrative of success presented to inspectors (Bradbury and Roberts-Holmes 2017a).

This influence from the rest of primary education, part of the wider 'schoolification' critique (Moss 2008; OECD 2006), is evident in current political discourse around the early years. In 2017 an Ofsted report on good practice in Reception titled 'Bold Beginnings: The Reception Curriculum in a sample of good and outstanding primary schools' was heavily criticised by practitioners for recommending more direct teaching of literacy and mathematics (Ofsted 2017). The report, which was based on 41 primary schools, was described in an open letter organised by the campaign group Keep Early Years Unique as 
recommending potentially damaging 'developmentally inappropriate practice' based on a small and flawed sample (KEYU 2017). Around the same time, a government consulation on primary assessment in general was conducted, and the Department of Education's response to the submissions included a decision that the early learning goals which form the EYFS Profile should be revised 'to make them clearer and align them more closely with teaching in key stage 1' (DfE 2017a). This recommendation came alongside the proposed return of Baseline Assessment in 2020.

Similar contestations continue internationally, notably in the response of early childhood academics to a 'mini-PISA' assessment for five-year-olds organised by the OECD (Moss et al, 2016; Urban and Swadener, 2016). Early years remain a site where high stakes testing and discourses of 'quality' (Hunkin 2016) are resisted though professional discourses which emphasise care for the child and a broad curriculum based on play. However, in England this resistance is limited in its impact, given the depth of the neoliberal policy incursion into education. As a result, I argue that early years is dominated by a particular model of what is means to be a 'good learner' defined by policy, which is distinctly neoliberal in nature, and exclusionary.

\section{Theorising student subjectivities}

This discussion of learner subjectivities in the early years of education is underpinned by the idea that dominant discourses shape models of the 'good' and 'bad' learner, which children are compared against. Foucault's notion of discourse is used here to describe particular frameworks of meaning which 'constitute rather than simply reflect social reality' (Ball 2005, p. 5); discourses are productive of 'truths' within a setting, which then appear to be preexisting. Thus, while it might appear to always have been so, the ideas contained in a policy document, for example, produce particular notions of who is successful in early years and how we can assess this success. Historically and geographically specific discourses shape 
how we understand the learner and the teacher and their relationship to one another in a particular time and place. Furthermore, dominant discourses relating to class, 'race', gender and dis/ability create intelligible spaces for some but not all children to be seen as 'good' learners, close the ideal (Youdell, 2006).

The concept of an idealised learner subjectivity has a long history in the discussion of the 'ideal client' of education (Becker 1952; Gillborn 1990; Walkerdine 1990). More recently, Youdell's work has discussed how 'students' subjectivities are entangled with schools' notions of different "sorts" of students and learners' (2006, p. 2) drawing on Judith Butler's work on identity as performative $(1990 ; 1997)$. The subject is constituted through discourse, which delimits intelligibility; as Butler argues, 'Subjects are constituted through norms which, in their reiteration, produce and shift the terms through which subjects are recognised' (2010, p4). By considering the expectations placed on children as learners, the intention here is to consider how children can be recognisable as good learners, in relation to the operating norms of the classroom. Youdell discusses how some pupils are constituted as 'impossible learners', outside the possibility of educational success, while others are rendered intelligible as acceptable learners $(2006 ; 2010)$. This conceptualisation of how learner subjectivities can operate has been used, both by Youdell and others, to consider how some groups of children are excluded from acceptability as they are not intelligible as good learners within discourses that operate as 'regimes of truth' (Foucault 1980). For example, the association of the ideal learner with a white, middle-class ideal positions entire cohorts of children in inner city schools as a 'difficult intake', who will inevitably have low levels of attainment (Bradbury 2013d). These ideas have also been developed further to explore the complex ways in which high-attaining students from marginalised groups can be dismissed as inauthentic learners, accused of learning for the 'wrong' reasons (Archer 2008; Bradbury 2013c). 
A particular interest here is the shifting form of the ideal learner identity, alongside policy change. It is argued that within a neoliberal policy framework dominated by the idea of the market, competition, accountability and individualism, the ideal learner is shaped by distinctly neoliberal values, so that in early years the child is expected to become a 'neoliberal subject' (Walkerdine 2003). This subject is responsible and self-regulating, reflective, flexible, and self-transforming, among other attributes (Francis and Skelton 2005, p. 124), and this model is discursively produced through the expected goals of the statutory assessment (Bradbury 2013a). We can conceptualise this production of an ideal through policy as a form of 'ethnopolitics', which 'concerns itself with the self-techniques by which human beings should judge themselves and act upon themselves to make themselves better than they are' (Rose 2001, p. 18). Thus, the production of neoliberal identities in early years can be seen as part of a broader strategy through which the subject is constituted in relation to neoliberal values.

It should be noted that this is not an explicit model, but one which is implicit in the content of assessments, policy documentation and in teachers' every-day discourse. It may also operate in tension other notions of 'success' in schools, which may be restricted to raw attainment in tests, or indeed more recently, the notion of 'good progress' (Bradbury and Roberts-Holmes 2017a). However, I argue here that the 'turn to character' (Allen and Bull 2018) represented by Character Education, alongside other discourses about students' attitudes to learning such as 'growth mindset' suggest this wider understanding of what is means to be a good learner still dominates. Character Education has become a solution to educational problems, under the Coalition and Conservative governments (2010-15 and 2015-), where "”character strengths" such as optimism, resilience, and grit [are] located as key factors shaping academic and other life outcomes' (Bull and Allen 2018, p. 1). As I discuss further below, these and other individualising discourses locate the solution to 
disparities in attainment in the individual child, while downplaying the role of structural inequalities.

\section{The research studies}

This discussion is based on two qualitative research projects undertaken in primary schools in England in the late 2000s and in 2017. This is not an attempt at a longditudinal study, but rather a way of considering shifting discourses among teachers under different policy regimes. The first project, funded by the Economic and Social Research Council, aimed to explore the classroom practices associated with the statutory assessment in Reception, the EYFS Profile (hereafter the EYFSP project). Data collection involved methods influenced by ethnography including long-term observation in the classroom (at least once per fortnight for one year), repeated interviews with classroom teachers and school leaders, and document collection of policies, assessments and classroom groupings. Interview schedules focused on the use of the assessments and its impact on the classroom. The research sites were two schools both located in inner London serving diverse and lower income populations, which I named St Mary's (a Church of England school) and Gatehouse (a community school). While I have discussed the findings from this project elsewhere (Bradbury, 2013c), here I reflect on these data as juxtaposed with more recent data from the second project.

The Grouping project explored the use of grouping by 'ability' in classrooms for children aged 3-7 (known as Early Years and Key Stage 1). This project was funded by the National Education Union, which is the largest teachers' union in England, and was conducted with a co-researcher X. Data collection involved four hour-long focus groups with teachers, with questions focused on the use of groups for different subjects and age groups, and how policy on grouping was decided. Following this, quantitative data was collected through an England-wide survey of teachers $(n=1373)$ including questions on the extent and nature of grouping and opinions on the practice. This survey also included some free text 
responses which provided a large volume of additional written responses. Finally, 12 individual interviews with teachers and school leaders were conducted at four case study schools located in different regions of England, to explore in more depth how teachers used grouping and their reasons for doing so. Sampling for the focus groups and interviews was opportunistic, based on access to teachers and schools, but the participants represented a range of different geographical locations, types of school and stages of their teaching careers. There was no requirement to be associated with the union for participation in the interviews or survey, but focus group participants were union members. Here I use data from this project (labelled as Grouping project) mainly from the focus groups and interviews (with FG denoting the focus group data and interviews individually labelled) and some written comments from the survey (denoted by a W). Both projects were conducted using the ethical guidelines of the British Education Research Association and went through ethical approval at the host institution.

Data from both projects were analysed independently in relation to the guiding research questions of the project, and then returned to for the purposes of this paper, with an attempt to draw out further how an ideal learner subjectivity is created and maintained in the neoliberal classroom. Data from the second project was analysed in relation the finding from the first project that policy created an ideal of a self-regulating and self-improving learner, alongside the developing literature on learner subjectivities in education.

\section{Policy and neoliberal child/learner subjectivities}

Here I set out how data from both projects suggests that an ideal learner subjectivity that was neoliberal in character operates in the early years of primary education. This analysis is premised on the connection between the content and form of assessments and the creation of an idealised student subjectivity (Bradbury 2013b); it suggests that assessment informs pedagogy, particularly where the assessment is 'high stakes' (Stobart 2008). This leads to the 
question of how changing assessments alter the form of this ideal, and to what extent. This question of what is changing is important in early years as there is an international trend of 'schoolification', where practices increasingly resemble those used with older primary school children, and this includes shifts in assessments from those which consider attainment across the curriculum to those that focus narrowly on literacy and mathematics. Previously I have argued that the early years is unique in that children are assessed on their character and dispositions as well as their 'academic' attainment, for example in their 'willingness to learn' (Bradbury 2013a). This more recent narrowing as part of 'schoolification' might be assumed to alter an idealised student subjectivity in early years, so that what is valued is a child who is successful in English and Maths. As I suggest below, there are certainly indications that these subjects have a growing importance in early years. Moreover, the trend known as datafication (Bradbury and Roberts-Holmes 2017c; Lingard 2009), where teachers are increasingly focused on the production and analysis of attainment data, would suggest a need to focus on that which is measurable, not the more amorphous notions of attitudes and character. Again, there is some suggestion that what matters is what is measured in what I discuss below. However, the more recent research data suggest that, despite a narrowing of what is assessed (for example, in the first iteration of Baseline, the planned re-introduction of the assessment, and the plans to revise the current Early Learning Goals), the desire to assess children in early years more broadly remains. This can be seen in the elements of the Baseline Assessment which assessed 'Characteristics of Effective Learning' (Early Excellence 2016), the inclusion of 'self-regulation' into the new Baseline, and also in the wider discourses of Character Education and 'growth mindset' present in primary schools. Therefore it remains the case, I argue, that children in early years are judged against an idealised student subjectivity which demands high academic attainment and a self-improving and selfregulating attitude towards learning. I begin with the most important part of the idealised 
student subjectivity, the need to 'self-improve', before considering how growth mindset and mastery reshape this subjectivity. The analysis section ends with a discussion of the damaging effects of getting choice 'wrong'.

\section{The early years 'entrepreneur of the self'}

In early years classrooms, a large proportion of the day is spent in 'free play', where children independently choose an activity from a range which are set up inside and often also outside the classroom. This is in keeping with the EYFS curriculum which states:

Each area of learning and development must be implemented through planned, purposeful play and through a mix of adult-led and child-initiated activity. Play is essential for children's development, building their confidence as they learn to explore, to think about problems, and relate to others. Children learn by leading their own play, and by taking part in play which is guided by adults. (DfE 2017b, p. 9)

Alongside this free play there may be adult-led activities, and there is a general trend towards more direct teaching in Reception (Ofsted 2017). Nonetheless, children do have to engage in the act of choosing activities, and this act in itself is part of the process by which children are assessed. Notably, under the pre-2012 longer version of the EYFS Profile, children were judged against these statements within the Personal, Social and Emotional Development strand:

Displays high levels of involvement in selfchosen activities (PSED 1, Point 3)

Selects and uses activities and resources independently (PSED 1, Point 5)

Continues to be interested, motivated and excited to learn (PSED 1, Point 6).

Sustains involvement and perseveres, particularly when trying to solve a problem or reach a satisfactory conclusion (PSED 1, point 9). (QCA 2008)

Thus children's ability to self-regulate and self-improve was part of their overall level of attainment. As I have previously discussed (2013a), in the Reception classrooms I studied 
teachers idealised those who chose a range of different activities, while they also criticised those children who chose the same activity repeatedly; one teacher referred to two boys who always played with the train set as 'doing exactly the bloody same thing every day'. The acceptable alternative was to attempt a range of activities, while still maintaining what teachers saw as 'focus'; those that moved around too much were seen as lacking in concentration. This need to select and engage appropriately with activities suggests a neoliberal subjectivity committed to self-improvement; I characterise this as being an 'entrepreneur of the self’, using du Gay’s phrase (1996).

The shortened version of the EYFS Profile in operation since 2012 similarly demands a willingness to engage with new activities; Early Learning Goal 6 reads:

Children are confident to try new activities, and say why they like some activities more than others. They are confident to speak in a familiar group, will talk about their ideas, and will choose the resources they need for their chosen activities. They say when they do or don't need help. (DfE 2017b my emphasis)

Here children are expected to be engaged in their own project of self-improvement, and able to reflect on it, discussing what they like and do not like and where they need help. The ideal is a self-reflexive, confident learner who takes on new challenges.

More recently, the content of one form of Baseline Assessment (the first attempt to introduce a test at the beginning of Reception), including similar assessment points under the term 'Characteristics of Effective Learning'. These included:

Shows curiosity about objects and the world around them, and has particular interests.

Willing to try out new things and is open to new experiences.

Maintains focus for a period of time, showing high levels of engagement and paying attention to detail. 
Keeps on trying and doesn't give up at the first difficulty. (Early Excellence 2015)

These points, against which four-year-olds were assessed in their first weeks of school (as opposed to during the year, for the EYFS Profile), provide a model of the learner who is curious but focused, who shows they can persevere. This focus on perseverance - like the highest-grade PSED point above ('Sustains involvement and perseveres') - has echoes of the 'grit' discourse within Character Education (Allen and Bull 2018), a topic I return to below.

This need for self-improvement links with an idealisation of the concept of progress (Bradbury and Roberts-Holmes 2016a), where everyone must be continuously moving on through pre-determined stages. This was clear in the grouping project: when asked to explain what is meant by the term 'ability', teachers' responses included a willingness to 'progress' and 'push themselves', and 'a resilience to persevere when things go wrong' (alongside many other definitions, which I do not have space to discuss here).

This concern for progress is complex, guided by the governing effects of data. It is not simply about moving everyone along, but the idea that, as one teacher respondent argued in previous research, 'nobody's allowed to fall behind' (Bradbury and Roberts-Holmes 2017a). This conceptualisation fits with the 'mastery' approach, as described here, and discussed further below:

If you look at it in terms of progression, at the moment maths might be children on an escalator, you have some at the bottom or some in the middle, some at the top and they'd all be moving in that direction, moving upwards. The Singapore maths approach is that you're all in a lift. You all get in the lift and you all go up at the same rate. (FG3)

Whichever way progress is conceptualised, the process of datafication - whereby that which is measurable and quantifiable is important - might suggest a shift away from assessing children's character. For example, the original tender for companies to produce a Baseline 
Assessment required that the majority of the content was focused on Literacy and Mathematics (DfE 2014b); it was a choice for Early Excellence to include the Characteristics of Effective Learning (and a popular choice, as the majority of schools opted for their version). Recent discussion of the 'schoolification' of early years has criticised the focus on Literacy and Mathematics; this process is both enabled and driven by datafication, as these are seen the most 'measurable' subjects (Bradbury, forthcoming), where children are most 'machine readable' (Williamson 2014). Indeed, the grouping project there was some evidence that children were viewed through the narrow lens of attainment in core subjects, as 'ability' was defined as success in English and Maths. For example, one teacher commented that 'ability' was 'Knowledge of how to apply phonics and understanding of maths concepts' (W) while another responded, 'Ability unfortunately is considered to be achievement in maths and literacy - that which we measure!' (W).

However, I would argue that the ideal learner subjectivity in early years remains broader than just high attainment in the core subjects, because - and this is where this age phase is in some ways unique - in early years children's characters and dispositions are measured too. This is shown by the inclusion of early learning goals relating to children's dispositions in the EYFS Profile and the inclusion of the Characteristics of Effective Learning in the most popular Baseline. It is also evident in recent policy, as the latest iteration of Baseline put out to tender was described thus:

The assessment should include an age-appropriate assessment of communication, language, and literacy as well as mathematics and should be clearly linked to the learning and development requirements of the Early Years Foundation Stage. We will also ask potential suppliers to explore ways in which it would be possible to assess some form of 'self-regulation' in their bids. (Government Online 2017) my emphasis)

This possible measure of 'self-regulation' has not been produced yet, but the inclusion of this point suggests that policy continues to demand a learner subjectivity that is controlled and 
entrepreneurial, with measurable forms of self-regulation. In doing so, as I argue in the final section of this paper, the policy locates the problem for those who do not succeed within the individual. Teachers still have a broader view of what it means to be a 'good learner' in early years which includes the neoliberal values of individual self-improvement; I now turn to how this broader view has been encouraged by the recent trends of 'growth mindset' and 'mastery'.

\section{Growth mindset and Mastery}

These two phrases were repeatedly used in the grouping project suggesting contemporary discourses within schools which are seen as positive developments ${ }^{\mathrm{i}}$. Growth mindset is an approach based on Carol Dweck's book Mindsets (2006), a 'million copy bestseller', which argues that intelligence can be increased with effort, so that a 'growth mindset' is a route to success. Mastery is an approach to mathematics teaching which 'breaks subject matter and learning content into units with clearly specified objectives which are pursued until they are achieved. [It] can be contrasted with other approaches which require pupils to move through the curriculum at a pre-determined pace' (EEF nd). The TES devotes a whole sub-site to resources related to Mastery, and explains the focus on each individual child achieving a 'deep, conceptual understanding of the topic' (TES 2017b).

These two terms were used as justifications for alternative pedagogical practices to grouping by 'ability' (here including teachers from Year 1 and 2, teaching children up to age seven):

As Mastery is being taught across subjects allowing children to excel in each subject ability groupings are used less. (W, Grouping project)

We use Growth Mindset in our school and encourage the children to challenge themselves to select their choice of activities in English and Maths, therefore do not see the need to teach in ability groups. (W, Grouping project) 
Children put into fixed ability groups at the beginning do not have the opportunity to develop growth mind sets and raise their attainments levels to the best. They also can lack a 'can do attitude.' And can develop a dependency on the adult who works with the group. (W, Grouping project)

Here we see how Mastery and Growth mindsets are juxtaposed with ability groups so that the former are more positive about children and engage with the language of attainment ('allowing children to excel', 'raise their attainment levels to the best'). Growth mindsets are the opposite of dependency on teachers and lacking a 'can do attitude'. However, some teachers did comment on the problems of supporting children under a 'growth mindset approach':

my school have tried to get rid of ability groups this year and have adopted a 'growth mindset' approach where children sit in mixed ability groups and the teacher 'helicopters' around so that all children are monitored. I find this difficult as I have children dotted around the room who I can't always get to and they end up struggling. (W, Grouping project)

These 'buzzwords' have been described in the education press as the latest educational fad, where 'Even good research, by the time it reaches the classroom - it's become transmogrified into something that bears no resemblance to its original version' (Bennett in TES 2017a). It is certainly clear from these survey responses that the terms at the very least, if not the original ideas, are commonplace in schools at present. This matters here as Growth mindsets and Mastery relate to children as individual learners, with their trajectories through school. Growth mindset focuses on a child's attitudes to learning. Thus, they both encourage and promote an idea of the individual student who has a particular approach to school - and ideally one which is self-regulating and self-improving. This this is most obvious in the use of 'challenges' for students within Growth mindset approaches, in which children pick the level of activity they feel is appropriate for them, which I discuss below. 


\section{Getting choice 'wrong'}

In a context framed by Growth mindset, choice takes on a new role, well beyond choosing in free play. One frequently cited example of this approach is the use of challenges for children where they are required to select their level of difficulty. These are sometimes known as 'Chilli challenges' where the levels are hot, spicy or mild (presumably an attempt to lessen the hierarchy of high, middle and low). Traffic light colours of red, orange and green are also used. Teachers in the Grouping project explained this approach:

For all other subjects apart from phonics I work a self-differentiated curriculum where
the children choose the level of challenge and this has enabled children to challenge their
own learning and learn from others. It encourages risk taking. (W, Grouping project)

We have started using mixed ability groups this year. I was sceptical at first but now children decide which of 3 challenges they will attempt - mild spicy or hot (our chilli challenges, success criteria linked to LIs ${ }^{\mathrm{ii}}$ ) and most children respond well and push themselves! This is based on growth mindset ideas. (W, Grouping project)

I do not believe in grouping and think it is very important for children to make informed choices, understanding where they are and where they need to go next. In this way they are not limited. Children often surprise you with what they can achieve if they are ambitious. Young children should not be pigeon holed and should not be limited. They should take an active part in their learning and this should include the choices they make about the level they access activities. (W, Grouping project)

Again, we see how this approach expects children to be able to choose what they should attempt, to 'push themselves', and take risks. Children are required to make 'informed choices', with an understanding of 'where they are and where they need to go next'. This is an individual discourse which focuses on the child as the main determinant of their success ('taking an active part in their learning'), informed by wider neoliberal conceptions of the self. As Rose argues: 
modern individuals are not merely "free to choose", but obliged to be free, to understand and enact their lives in terms of choice. They must interpret their past and dream their future as outcomes of choices made or choices still to make. Their choices are, in turn, seen as realizations of the attributes of the choosing persons - expressions of personality - and reflect back upon the person who has made them. (Rose 1999, p. 87 emphasis in original)

Of course, as with any choice, there is a risk of getting it wrong, and like in the choices made in free play, getting it wrong further positions the child as lacking - the 'reflection back' that Rose describes above. As one teacher explained:
When children are working independently and they're choosing their level, where, as I've said, they've chosen completely the wrong level for them, so they've gone way past their next step. [...] So, they can have a go. I mean, sometimes I found that backfires and there are some children who will go, "Well, I'm doing all of the red ones" and then will get them, actually, all wrong [...] so it's trying to balance the, "It's lovely you've got the ambition but, actually, make sure you can do those ones, first." (Teacher, Grouping project)

This quote suggest that it is possible to get self-chosen tasks 'wrong', to be 'defective' or 'flawed consumers' (Bauman 2005), even where the approach taken emphasises 'pushing yourself' and self-improvement. It is clear that being responsible for your own progress involves having an accurate sense of where you are and what you can do, not simply having 'ambition'. This means there are many ways to get it 'wrong', to fail in the very act of choosing, before even beginning the task. Engaging in choice in this way involves being selfreflective and aware of your own position.

The idea of getting choice 'wrong' contradicts the rational choosing model of neoliberalism, as most recently recognised in the use of behavioural economics (Bradbury et al. 2013) where 'nudges' are used to encourage particular choices within a 'choice architecture'. This failure is inflected with classed and raced distinctions, as seen in the New 
Labour policy of choice advisers in the 2000s, where disadvantaged parents were given additional advice to help them choose schools appropriately and realistically (Exley 2009).

\section{Discussion: Individual success, individual failure}

The linkages between neoliberal policy and the reproduction of social inequalities by class, 'race', gender, dis/ability and many other factors are well established in the research literature (Ball 2017; Gewirtz et al. 1995; Gillborn and Youdell 2000). This discussion explores how the specifics of the production of an ideal learner identity in the first years of school works to exclude some children from positions of acceptability or recognisability as 'good learners', so that they are rendered 'impossible' (Youdell 2006) and outside of educational acceptability. I focus on the importance of choice, and how the child is made responsible for 'good' and 'bad' choices in ways which are exclusionary, and how this relates to how families are seen as engaging with education, or not.

As discussed above, choice is a key principle of early years practice, in that children are able to choose activities during free play. But not all choices are equal, and the implications of choosing 'wrongly' are that the child does not learn the 'right' things, and they are positioned as a 'bad chooser', like Bauman's (2005) 'defective consumers'. As Bauman argues, 'Freedom to choose does not mean that all choices are right - there are good and bad choices $[\ldots]$ the kind of choice made is the evidence of competence or its lack' $(2005,76)$. In the ethnographic EYFSP study, children who chose higher status activities such as reading, writing or maths puzzles were constituted as the self-improving, responsible and self-aware good learners, while those who chose lower status but perhaps more enjoyable activities such as riding tricycles were understood as not properly engaging with the project of learning (discussed in more detail in Bradbury 2013d). This judgement of engagement has 
classed implications as children's choices may be based on familiarity with and confidence in particular activities.

Moreover, the extent to which each child was seen in general as an 'entrepreneur of the self' was affected by understandings of their racialised, class and gendered identity, based largely of perceptions of family background. Children from poorer homes who did not attend school were framed as failing to take up the opportunity of education, while working-class children with 'educationally-orientated' families were seen positively as self-improving. Here we see how the assessment of children's attitudes to learning can be linked in simplistic ways to their family background in ways which are inevitably reproductive of social disadvantage. As one teacher commented in the Grouping project 'we have no idea what their home life is like and that obviously determines how well they're going to do in school' (FG3). Another commented:

The majority of the pupil premium are with me who are just one step behind where they should be. But then our pupil premium children don't do any reading at home, none. (Teacher, Grouping project)

This assumption that reading is not done in 'pupil premium families' illustrates how easily links are made between parents' choices about engagement with school work and children's attitudes to school. The presumed choice not to read at home, seen through a neoliberal lens, is irrational, and positions the 'pupil premium' family as failing to take up opportunities to improve themselves; the child is 'behind' and outside of educational acceptability. As Rose describes, within the project of 'responsible citizenship', some 'remain outside this regime of civility' (1999, p. 88). These children are unrecognisable as 'good' learners, unable to occupy positions of success. 


\section{Conclusion}

In early years the need to become a 'little neoliberal' is governed by policy, which seeps into expectations and practice in classrooms, as we see in the research data above. This is not a static and stable demand, but one which evolves as policy shifts. The 'schoolification' and concomitant datafication of early years, where Mathematics and Literacy have increased prominence in a system which values what is measured, operate at times in tension with a wider model of what constitutes a 'good learner'. However, the continued measurement of children's attitudes and dispositions in statutory assessments, and teachers' enthusiasm for this, mean that key commonalities with Walkerdine's neoliberal subject remain. This is apparent in the value placed on choosing appropriately and improving oneself - whether this be through selecting the right activities, adopting the right 'mindset' or showing 'grit' and perseverance.

Importantly, the idea of self-improvement and being an 'entrepreneur of the self' is premised on individual responsibility for success or failure. Policy and current educational trends provide 'norms of enterprising, self-actualizing responsible personhood' (Rose 1999, p. 18): if the child does not pick the appropriate chilli challenge or chooses low status activities during free play, then they are required to deal with the consequences of their irrational decision. If the children from 'pupil premium families' mentioned above are 'one step behind' then it is seen as their responsibility as they have chosen badly not to read at home. This removes structural factors from the discussion; after all, not choosing irrationally within a system of free choice 'is easily, without a second thought, interpreted as choosing something else instead' (Bauman 2005:75).

Meanwhile, as Rose argues, for those who are excluded, 'problems are represented in a new way, and are hence amenable to new modes of intervention' $(1999$, p. 88). The discourses of explanation around why some groups of children persistently 'underperform' in 
schools can be seen in this light, as a continuous project of justifying exclusion. Most recently, what Taylor calls 'stigmatising character discourses' within Character Education, involve judging children's attitudes to learning; these discourses 'leave the burden of responsibility for particular social outcomes in life and the labour market with individuals and their ability to cultivate their own human capital' (2018, p. 1).

This 'turn to character' (see Allen and Bull 2018; Bull and Allen 2018; Burman 2018; Morrin 2018 for further discussion), is the latest justificatory narrative for disparities in attainment. Character Education and Growth mindset discourses, like other circulating social policy trends such as network theory and the influence of neuroscience are examples of how new 'insights' can be translated into policy (McGimpsey et al. 2017), in ways which adapt the subjectivating force of policy. As McGimpsey et al argue, the different subjects represented through policy, both irrational and rational choosers, represent a diversification of the policy subject:

different narratives become possible, different regulatory technologies are developed and deployed, and there are methodological shifts in education and youth policy making as economic theory is adjusted to incorporate a range of new assumptions about human nature and their individual choosing behaviours (McGimpsey et al. 2017, p. 920)

This diversification can be seen as strategic and necessary for the continuation of neoliberal regime in an era of uncertainty, symptomatic of a 'change of emphasis' in policy-making (Ball 2012, p. 95) and the 'continued mongrelisation' of neoliberalism (Peck 2010, p. 24). To conclude, neoliberal policy shapes the lived experiences of children in their first years of primary school in England by providing a model of an ideal learner subjectivity who is selfimproving and entrepreneurial. But not all children are recognisable as this ideal learner, based on raced and classed discourses, and those who do not engage or choose irrationally, are placed further outside the realm of educational acceptability. In an era where early childhood education is affected by neoliberal ideology internationally (refs), and where 
policy from England is often 'borrowed' by other countries (ref phonics tests) this emphasis on the individual child as self-improving learner has relevance in wider debates about the impact of neoliberal policy on early educational inequalities.

\section{References}

Allen, K., \& Bull, A. (2018). Following Policy: A Network Ethnography of the UK Character Education Policy Community. Sociological Research Online Available at: https://doi.org/10.1177/1360780418769672

Archer, L. (2008). The impossibility of minority ethnic educational 'success'? An examination of the discourses of teachers and pupils in British secondary schools. European Educational Research Journal, 7(1), 89-107.

Ball, S. (2005). Education Policy and Social Class: The Selected Works of Stephen J. Ball. London: Routledge

Ball, S. J. (2012). The reluctant state and the beginning of the end of state education. Journal of Educational Administration and History, 44(2), 89-103.

Ball, S. J. (2017). The education debate (third edition). Bristol: Policy Press.

Bauman, Z. (2005). Work, consumerism and the new poor (2nd ed.). Maidenhead: Open University Press.

Becker, H. S. (1952). Social-class variation in the teacher-pupil relationship. Journal of Educational Sociology, 25(8), 451-465.

Bradbury, A. (2013a). Education policy and the 'ideal learner': producing recognisable learner-subjects through early years assessment. British Journal of Sociology of Education, 34(1), 1-19.

Bradbury, A. (2013b). From model minorities to disposable models: the de-legitimisation of educational success through discourses of authenticity. Discourse: studies in the cultural politics of education, 34(4), 548-561.

Bradbury, A. (2013c). Understanding Early Years Inequality: policy, assessment and young children's identities. London: Routledge.

Bradbury, A. (under review). Datafied at four: the role of data in the formalisation of early childhood education in England Learning Media and Technology, Special Issue: Datafication

Bradbury, A., McGimpsey, I., \& Santori, D. (2013). Revising rationality: the use of 'Nudge' approaches in neoliberal education policy. Journal of Education Policy, 28(2), 247267. 
Bradbury, A., \& Roberts-Holmes, G. (2016). 'They are children, not robots': The Introduction of Baseline Asssessment. London: ATL/NUT.

Bradbury, A., \& Roberts-Holmes, G. (2017a). Creating an Ofsted story: the role of early years assessment data in schools' narratives of progress. British Journal of Sociology of Education, 38(7), 943-955.

Bradbury, A., \& Roberts-Holmes, G. (2017b). Grouping in Early Years and Key Stage 1: a 'necessary evil'? London: National Education Union.

Bradbury, A., \& Roberts-Holmes, G. (2017c). The Datafication of Early Years and Primary Education: Playing with numbers.

Bull, A., \& Allen, K. (2018). Introduction: Sociological Interrogations of the Turn to Character. Sociological Research Online Available at: https://doi.org/10.1177/1360780418769672

Burman, E. (2018). (Re)sourcing the Character and Resilience Manifesto: Suppressions and Slippages of (re)presentation and Selective Affectivities. Sociological Research Online Available at https://doi.org/10.1177/1360780418769671

Butler, J. P. (1990). Gender trouble: feminism and the subversion of identity. London: Routledge.

Butler, J. P. (1997). Excitable Speech: A politics of the performative. New York: Routledge. BWB. (2015). Better without Baseline: four core reasons.

Carr, M. (2013). Making a borderland of contested spaces into a meeting place: the relationship from a New Zealand perspective. In P. Moss (Ed.), Early Childhood and Compulsory Education: Reconceptualising the relationship (pp. 92-112). London: Routledge.

Dahlberg, G., \& Moss, P. (2005). Ethics and politics in early childhood education. London: RoutledgeFalmer.

DfE. (2014a). Early Years (under 5s) Foundation Stage Framework (EYFS). Retrieved 24 October 2017, from https://www.gov.uk/government/publications/early-yearsfoundation-stage-framework--2

DfE. (2014b). Reception baseline: approval process for assessments. Retrieved 13 March 2018, from https://www.gov.uk/guidance/reception-baseline-approval-process-forassessments

DfE. (2016). Reception baseline assessment: guide to signing up your school (Updated 16 April 2016). Retrieved 6 March 2017, from https://www.gov.uk/guidance/receptionbaseline-assessment-guide-to-signing-up-your-school

DfE. (2017a). Primary assessment public consultations: government response. Retrieved 23 March 2018, from https://www.gov.uk/government/speeches/primary-assessmentpublic-consultations-government-response

DfE. (2017b). Statutory Framework for the Early Years Foundation Stage. from https://www.foundationyears.org.uk/files/2017/03/EYFS_STATUTORY_FRAMEW ORK_2017.pdf

Du Gay, P. (1996). Consumption and identity at work. London: Sage.

Dweck, C. S. (2006). Mindset: The new psychology of success: Random House Incorporated.

Early Excellence. (2015). Baseline Statements and Exemplification. Retrieved 1 June 2018, from http://earlyexcellence.com/wp-content/uploads/2015/06/EX_EExBAR_Statements_and_Exemplification1.pdf

Early Excellence. (2016). EExBA - YR Baseline Assessment. Retrieved 14 March 2017, from http://earlyexcellence.com/eexba2016 
EEF. (nd). Mastery learning. Retrieved 3 June 2018, from https://educationendowmentfoundation.org.uk/evidence-summaries/teaching-learningtoolkit/mastery-learning/

Exley, S. (2009). Emerging discourses within the English 'choice advice' policy network. London Review of Education, 7(3), 249-260.

Foucault, M. (1980). Power-knowledge: selected interviews and other writings, 1972-1977. Brighton: Harvester Press.

Francis, B., \& Skelton, C. (2005). Reassessing gender and achievement: questioning contemporary key debates. London: Routledge.

Gewirtz, S., Ball, S., \& Bowe, R. (1995). Markets, choice and equity in education. Buckingham: Open University Press.

Gillborn, D. (1990). 'Race', ethnicity and education: teaching and learning in multi-ethnic schools. London: Unwin Hyman.

Gillborn, D., \& Youdell, D. (2000). Rationing education: policy, practice, reform and equity. Buckingham: Open University Press.

Gillies, V., Edwards, R., \& Horsley, N. (2017). Challenging the politics of early intervention: who's' saving'children and why. Bristol: Policy Press.

Gunnarsdottir, B. (2014). From play to school: are core values of ECEC in Iceland being undermined by 'schoolification'? International Journal of Early Years Education, 22(3), 242-250.

Government Online. (2017). Tender: Reception Baseline Assessment in England. Retrieved 1 June 2018, from http://www.government-online.net/reception-baseline-assessmentin-england/

Hunkin, E. (2016). Deploying Foucauldian genealogy: Critiquing 'quality' reform in early childhood policy in Australia. Power and Education, 8(1), 35-53.

KEYU. (2017). A Collective Open Letter in Response to Bold Beginnings Report coordinated by Keep Early Years Unique. Retrieved 13 March 2018, from https://www.keyu.co.uk/bold-beginnings/

Lingard, B. (2009). Testing times: The need for new intelligent accountabilities for schooling. QTU Professional Magazine, 24(November), 13-19.

McGimpsey, I., Bradbury, A., \& Santori, D. (2017). Revisions to rationality: the translation of 'new knowledges' into policy under the Coalition Government. British Journal of Sociology of Education, 38(6), 908-925.

Morrin, K. (2018). Tensions in Teaching Character: How the 'Entrepreneurial Character' is Reproduced, 'Refused', and Negotiated in an English Academy School. Sociological Research Online Available at: https://doi.org/10.1177/1360780418769670

Moss, P. (2008). What Future for the Relationship between Early Childhood Education and Care and Compulsory Schooling? Research in Comparative and International Education, 3(3), 224-234.

Moss, P. (Ed.). (2013). Early Childhood and Compulsory Education: Reconceptualising the relationship. London: Routledge.

Moss, P., Dahlberg, G., Grieshaber, S., Mantovani, S., May, H., Pence, A., et al. (2016). The Organisation for Economic Co-operation and Development's International Early Learning Study: Opening for debate and contestation. Contemporary Issues in Early Childhood, 17(3), 343-351. 
OECD. (2006). Starting strong II: Early childhood education and care: OECD.

Ofsted. (2017). Bold beginnings: The Reception curriculum in a sample of good and outstanding primary school. Retrieved 13 March 2018, from https://www.gov.uk/government/uploads/system/uploads/attachment_data/file/663560 128933_Ofsted_-_Early_Years_Curriculum_Report_-_Accessible.pdf

Peck, J. (2010). Constructions of neoliberal reason: Oxford University Press.

QCA. (2008). The Early Years Foundation Stage Profile Handbook. London: Qualifications and Curriculum Authority.

Rose, N. (1999). Powers of freedom: Reframing political thought: Cambridge university press.

Rose, N. (2001). The politics of life itself. Theory, culture \& society, 18(6), 1-30.

Rose, J., \& Rogers, S. (2012). Principles under pressure: student teachers' perspectives on final teaching practice in early childhood classrooms. International Journal of Early Years Education, 20(1), 43-58.

STA. (2016). Reception baseline comparability study. Retrieved 6 April 2017, from https://www.gov.uk/government/publications/reception-baseline-comparability-study

Stobart, G. (2008). Testing times: the uses and abuses of assessment. London: Routledge.

Taylor, N. (2018). The Return of Character: Parallels Between Late-Victorian and TwentyFirst Century Discourses. Sociological Research Online, 1360780418769679.

TES. (2017a). Is growth mindset the new learning styles? Retrieved 3 June 2017, from https://www.tes.com/news/weekend-read-growth-mindset-new-learning-styles

TES. (2017b). Maths Mastery. Retrieved 3 June 2018, from https://www.tes.com/teachingresources/teaching-for-mastery-in-primary-maths

Urban, M., \& Swadener, B. B. (2016). Democratic accountability and contextualised systemic evaluation. A comment on the OECD initiative to launch an International Early Learning Study (IELS). International Critical Childhood Policy Studies Journal, 5(1), 6-18.

Walkerdine, V. (1990). Schoolgirl Fictions. London: Verso.

Walkerdine, V. (2003). Reclassifying Upward Mobility: femininity and the neo-liberal subject. Gender and Education, 15(3), 237 - 248.

Williamson, B. (2014). Reassembling children as data doppelgangeers: How databases are making education machine-readable, Powerful Knowledge Conference. University of Bristol.

Youdell, D. (2006). Impossible bodies, impossible selves: exclusions and student subjectivities. Dordrecht: Springer.

Youdell, D. C. (2010). Performativity: making the subjects of education. In Z. Leonardo (Ed.), Handbook of Cultural Politics in Education. Rotterdam: Sense Publishers.

\footnotetext{
${ }^{\mathrm{i}}$ I should be clear here that I am not commenting on the efficacy of either approach, merely discussing the impact they have on concepts of the ideal learner.
} 
${ }^{\text {ii }}$ Learning Intentions 